\title{
Hvordan opstår en tsunami? - 4 hovedårsager til katastrofale bolger
}

\section{Af geolog Ulla V. Hjuler, GeologiskNyt}

Temaet i dette nummer er tsunamien i Det Indiske Ocean 2. juledag 2004. I de følgende artikler beskrives årsager til og følgevirkninger af katastrofen. Først skal vi dog lige kigge kort på de fire hovedårsager til tsunamiers opståen.

\section{Meteorit/asteroide}

Hvis en asteroide på $1 \mathrm{~km}$ i diameter ramte Jorden - fx i Stillehavet, ville der opstå gigantiske tsunamier - og desuden voldsom jordskælvsaktivitet, ødelagt ozonlag samt at det meste liv på vores Jord vil blive udslettet. Krateret vil få en diameter på 20-25 km. Havbunden bliver blottet og uhyrlige mængder vand vil på få sekunder slynges i alle retninger ud fra krateret. Bølgen flader ud, men så snart den møder modstand ved en kyst, tårner den sig op og med eksplosionsagtig kraft slår ind over land. Det meste af Danmark ville formentlig blive oversvømmet af sådan en bølge, og under dens tilbagetrækning, der vil være stort set lige så voldsom som dens anslag, vil bølgen rive alt med sig - som det også var tilfældet ved tsunamien i Det Indiske Ocean. Den frigivne energi vil være omtrent 3,7 x $10^{20} \mathrm{~J}$ ! Løfter man en håndvægt på $5 \mathrm{~kg}$ én meter op, er den brugte energi kun $49 \mathrm{~J}$.

\section{Jordskælv}

Et kraftigt undersøisk jordskælv kan være årsag til en tsunami - det var det, der skete d. 26. december 2004 ud for det nordlige Sumatra. To oceanbundsplader stødte sammen vest for Sumatra i Sunda-graven, og ved den kollision blev den gennem lang tid opbyggede spænding, udløst $i$ et af de kraftigste jordskælv, der nogensinde er registreret, og i dagene efter fulgte adskillige voldsomme efterskælv.

Jordskælv kan også opstå, når en oceanbundsplade og en kontinentalplade støder sammen, som det er tilfældet med den oceaniske Nazca-plade, der skydes ned under den store sydamerikanske plade. D. 23. juni 2001 blev der således registreret et jordskælv på 8,1 på Richter-skalaen lige ud for kysten ved Peru. Også her forårsagede skælvet en tsunami, hvis bølgehøjde nogle steder nærmede sig $5 \mathrm{~m}$. På visse flade kystområder skyllede vandet over $3 \mathrm{~km}$ ind $\mathrm{i}$ landet.

Hvis Jorden rammes af en gigantisk asteroide med en diameter på over $1 \mathrm{~km}$, vil det meste liv på Jorden udslettet. (Computersimulering: Morten L. Hjuler, GeologiskNyt, 2004)

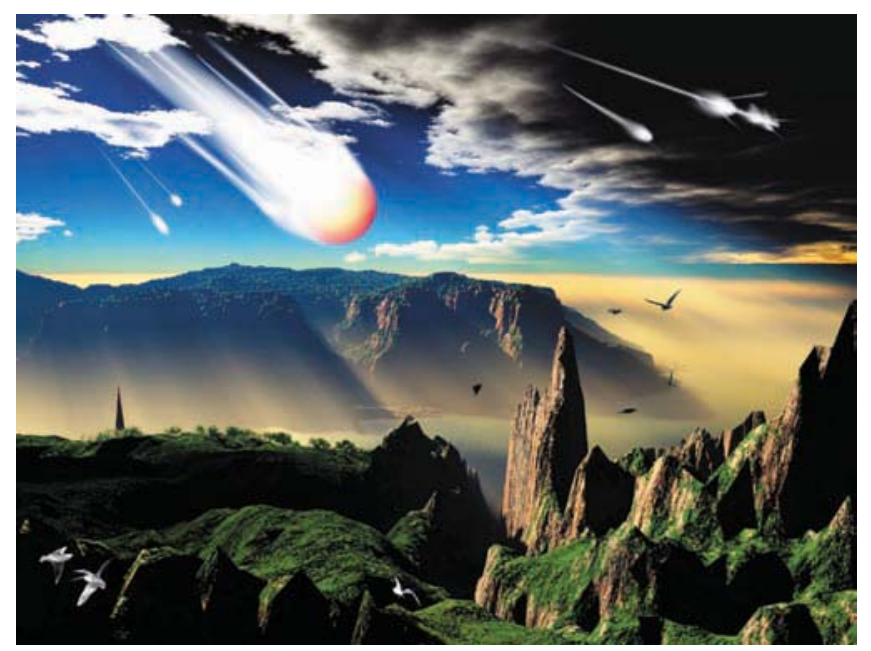

\section{Vulkaner}

Vulkanudbrud, der fx resulterer i, at en del af vulkanen kollapser, kan forårsage tsunamier. Vulkankegler, der er flere hundrede eller måske over 1.000 meter høje, svækkes af de processer, der skaber dem, nemlig voldsomme udbrud af smeltede bjergarter. Eruptionen flår siderne op eller skaber svaghedszoner i selve keglen, og tilstedeværelsen af varme, hydrotermale opløsninger svækker bjergarterne ved at omdanne dem til ler. Her er der en potentiel fare for kollaps.

Unzen i Japan er et stort vulkankompleks bestående af adskillige lavadomer (runde, stejle kupler høje opbygget af meget tyktflydende magma - typisk dacit eller rhyolit). Komplekset dækker et stort område nær Nagasaki. Under et voldsomt vulkanudbrud i Japan i 1792, kollapsede østflanken af den såkaldte "Mayu-yama-lavadome" og skabte en lavine, der væltede ned i Ariake-søen. Herved opstod en tsunami, som dræbte flere, end selve lavinen gjorde. Næsten 15.000 mennesker omkom.

\section{Submarine udskridninger}

Voldsomme undersøiske eruptioner kan også forårsage tsunamier. Ved et pludseligt flankebrud lige over eller lige under vandoverfladen kan en hel blok af vulkanens side sættes i bevægelse og give ophav til en tsunami - der kan være tale om en lokalt katastrofal tsunami, men udbredelsen vil ofte være lokal-ikke regional.

Regionale og endog globale hændelser kendes dog - fx forårsagede Krakataus udbrud i 1883 en så voldsom eksplosion og et efterfølgende kollaps, at det medførte ekstremt voldsomme tsunamier, der dræbte mere end 36.000 mennesker på Indonesiens kyster. Bølgerne nåede visse steder op i 40 meters højde og bevægede sig rundt om Jorden to gange.

Nogle antager, at den minoiske kultur er blevet udryddet efter eksplosionen, det efterfølgende kollaps af vulkanen og de deraf forårsagede tsunamier på Santorini 1490 f. Kr.

Også havbunden kan skride ud, som det skete under det andet Storegga-skred for ca. 8.200 år siden, hvor enorme mængder sediment kurrede ned af den norske kontinentalskrænt og godt 300 kilometer ud $i$ den dybe del af Atlanten. Skreddet forårsagede en regional tsunami, der er anslået til at have haft en højde på 11 meter visse steder langs Norskekysten, seks meter i Skotland, ti meter på Færøerne og hele 20 meter på Shetlandsøerne.

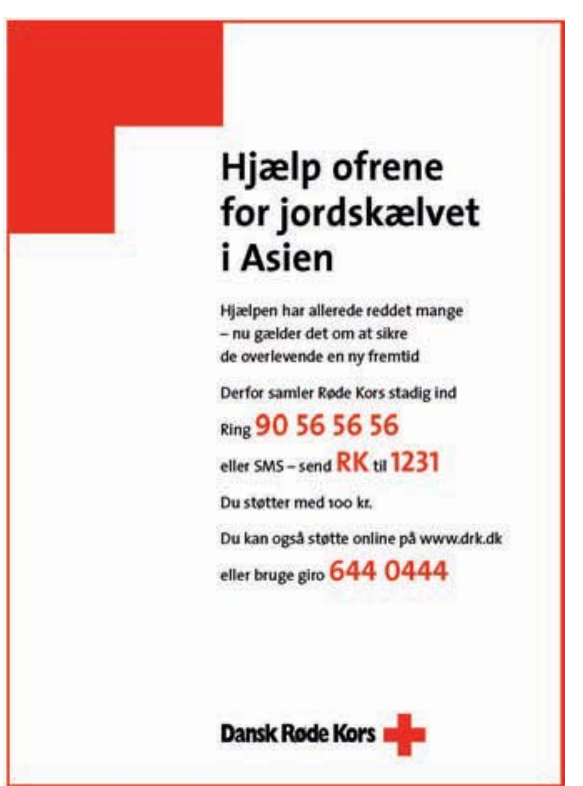

